\title{
Pendapatan Pedagang Ayam Kampung pada Pasar Tradisional di Kota Bengkulu
}

\author{
Income of Chicken Traders in Traditional Markets in the city of Bengkulu
}

\author{
Sutriyono dan J. Setianto
}

\author{
Jurusan Peternakan Fakultas Pertanian, Universitas Bengkulu \\ Jl. WR. Supratman, Kandang Limun, Bengkulu \\ Corresponding Author: jsetbkl@gmail.com
}

\begin{abstract}
The study aimed to analyze the income of native chicken traders in traditional markets in the city of Bengkulu, namely the Pasar Panorama and Pasar Minggu. Eleven respondents of native chicken traders were selected in this study. Data were collected by interview, filling out the questionnaire and direct observation; include the characteristics of respondents, fixed costs, variable costs, and revenue. The data obtained was tabulated and then income, $\mathrm{R} / \mathrm{C}$ was calculated, and linear regression analysis was performed to determine the variables that affect

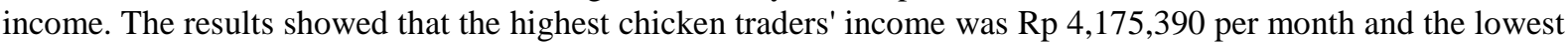

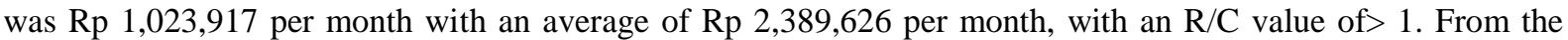
analysis of multiple linear regression, the equation $Y=-705323+10,64 X 1+17.789,28 X 2-229,57 X 3+148,57 X 4-$ $2,89 \mathrm{X} 5$ is obtained. The coefficient of determination $\left(\mathrm{R}^{2}\right)$ is 0.985 or $98.5 \%$. This value indicates that the cost of feed, the number of chickens purchased, chicken purchase price, chicken selling price, and transportation determine income of $98.5 \%$, and $1.5 \%$ is determined by other factors. Based on the $t$ test, the results show that the number of chickens purchased, chicken purchase prices and chicken selling prices affect the income of chicken traders, while the cost of feed and transportation does not affect the income of native chicken traders in Bengkulu Traditional Market.
\end{abstract}

Key words: Traditional markets, native chicken traders, income

\begin{abstract}
ABSTRAK
Penelitian bertujuan untuk menganalisis pendapatan pedagang ayam kampung di pasar tradisional di Kota Bengkulu, yaitu Pasar Panorama dan Pasar Minggu. Sebelas respoden pedagang ayam kampung dipilih dalam penelitian ini. Data dikumpulkan dengan cara wawancara, pengisian kuisioner dan pengamatan langsung; meliputi karakteristik responden, biaya tetap, biaya tidak tetap, dan penerimaan. Data yang diperoleh ditabulasi kemudian dihitung pendapatan, $\mathrm{R} / \mathrm{C}$, dan dilakukan analisis regresi berganda linier untuk mengetahui variabel yang berpengaruh terhadap pendapatan. Hasil penelitian menunjukkan bahwa pendapatan pedagang ayam kampung tertinggi Rp 4.175.390,- per bulan dan terendah Rp 1.023.917,- per bulan dengan rata-rata Rp 2.389.626,- per bulan, dengan nilai $\mathrm{R} / \mathrm{C}>1$. Dari analisis regresi linier berganda diperoleh persamaan $\mathrm{Y}=$ $705323+10,64 X 1+17.789,28 X 2-229,57 X 3+148,57 X 4-2,89 X 5$. Nilai koefisien determinasi $\left(R^{2}\right)$ adalah 0,985 atau $98,5 \%$. Nilai tersebut menunjukkan bahwa biaya pakan, jumlah ayam dibeli, harga beli ayam, harga jual ayam, dan transportasi menentukan pendapatan sebesar 98,5\%, dan 1,5\% ditentukan oleh faktor yang tidak diteliti dalam penelitian ini. Berdasarkan uji t diperoleh hasil bahwa jumlah ayam dibeli, harga beli ayam, dan harga jual ayam mempengaruhi pendapatan pedagang ayam, sedangkan biaya pakan dan transportasi tidak berpengaruh terhadap pendapatan pedagang ayam kampung di Pasar Tradisional Kota Bengkulu.
\end{abstract}

Kata kunci : Pasar tradisional, pedagang ayam kampung, pendapatan

\section{PENDAHULUAN}

Ayam kampung komoditas peternakan dan telah dibudidayakan oleh masyarakat secara luas di pedesaan di seluruh wilayah Indonesia. Budidaya ayam kampung oleh masyarakat pada umumnya dilakukan secara tradisional dengan cara dilepas, dengan tujuan sebagai penghasil telur dan daging, sebagai sumber gizi, sumber pendapatan, dan tabungan. Disamping itu, ayam kampung juga menghasilkan bulu untuk bahan industri dan kotoran sebagai bahan pupuk organik (Rasyaf, 2005) Beberapa kelebihan ayam kampung adalah tahan terhadap penyakit, mudah beradaptasi dengan lingkungan, pemeliharaannya mudah dan sederhana, 
biaya produksi murah, pemasaran mudah, dan harga jual produknya lebih mahal dari pada ayam ras (Nasution et al., 2016; Yuwanta, 2008). Daging ayam kampung lebih disukai masyarakat karena lebih kenyal dan berotot, kadar lemak lebih rendah dibandingkan dengan daging ayam broiler, dan cita rasa gurih (Krista, 2010). Kadar lemak yang rendah terutama pada daging bagian dada (Pane, 2006; Krista 2010). Oleh karena daging ayam kampung disukai masyarakat maka banyak warung dan rumah makan menyediakan masakan ayam kampung sebagai menu utama (Krista, 2010). Selera konsumen terhadap daging ayam kampung sangat tinggi sehingga permintaan ayam kampung dari tahun ke tahun semakin meningkat (Aman, 2011). Semakin meningkatnya ekonomi masyarakat, pendidikan, dan kesadaran akan gizi maka kebutuhan akan daging ayam juga meningkat. Pengembangan ayam kampung khususnya di pedesaan akan sangat membantu dalam menyediakan bahan pangan hewani yang bernilai gizi tinggi dan meningkatkan pendapatan. Pemiliharaan ayam kampung juga merupakan tabungan yang dapat dijual sewaktu-waktu untuk memenuhi kebutuhan rumah tangga yang mendesak (Chan dan Zamrowi, 1988 dalam Teti, 2002). Ayam kampung mempunyai keragaman yang cukup tinggi baik ditinjau dari performa maupun genetiknya dengan penyebaran yang sangat luas baik di desa maupun perkotaan. Disamping itu ayam kampung mempunyai tingkat adaptasi yang tinggi terhadap lingkungan, khususnya di Indonesia sehingga ayam kampung layak untuk dikembangkan. Pengembangan populasi ayam kampung dapat dilakukan dengan menggunakan sumberdaya lokal baik bibit maupun pakan dengan pemeliharaan yang dapat dilakukan secara ektensif. Sedangkan budidaya ayam ras perlu mendatangkan bibit, pakan, dan obat-obatan dari pabrik dan pemeliharaan harus intensif. Karena mudah untuk diusahakan maka populasi ayam buras yang didominasi oleh ayam kampung meningkat dari tahun ke tahun. Pada tahun 2014 populasi ayam buras di provinsi Bengkulu 2.709.080 ekor dan pada tahun 2017 naik menjadi 3.546.683 ekor (Anonim, 2018), berarti populasi ayam buras mengalami kenaikan $30,92 \%$ per tujuh tahun atau naik $10.31 \%$ per tahun atau naik 279.306,1 ekor per tahun.

Pemasaran produksi dari peternakan ayam kampung cukup mudah. Ada beberapa jalur pemasaran yang dilakukan oleh peternak, salah satu diantaranya adalah menjual ternak ke pasar tradisional. Menurut Perpres. No.112 tahun 2007, pasar tradisional dibangun dan dikelola oleh Pemerintah, Swasta, Badan Usaha Milik Negara (BUMN) dan Badan Usaha Milik Daerah (BUMD) termasuk kerjasama dengan pihak swasta. Tempat usaha dapat berupa kios, los, toko, dan tenda milik pedagang. Proses jual beli pada pasar tradisional pada umumnya dilakukan dengan tawar menawar unruk mencari kesepakan harga antara kedua belah pihak, yaitu antara penjual dan pembeli. Standar harga antar pedagang pada umumnya tidak sama. Jika sudah terjadi kesepakatan dalam tawar menawar selanjutnya terjadi jual beli. Kim (2015) mengemukakan bahwa pasar tradisional merupakan pasar lingkungan yang memainkan berbagai macam fungsi dan peran komersial serta sosial dari waktu ke waktu, yang ditandai sebagai tempat pertemuan sosial yang ramah, lokasi dekat dengan daerah pemukiman, dan tempat belanja yang nyaman. Berbagai macam jenis barang diperjualbelikan di pasar tradisional dan salah satunya adalah jual beli ayam kampung yang melibatkan pedagang pengumpul. Menurut Soedjana et.al. (1983), pedagang pengumpul melakukan kegiatan membeli ternak dari petani untuk dijual ke pasar hewan lokal dan ada juga yang dijual kembali ke petani lain di tingkat desa.

Pasar tradisional merupakan salah satu sarana dalam pemasaran ayam kampung. Permasalahan yang dihadapi dalam pemasaran ayam kampung dalam bentuk produk daging adalah adanya persaingan dengan daging ayam ras yang harganya jauh lebih murah sehingga terjadi persaingan dalam pemasaran. Persaingan dalam penjualan daging ayam kampung dengan 
daging ayam ras akan mempengaruhi omset penjualan yang dapat menurunkan pendapatan pedagang ayam kampung di pasar tradisional. Penelitian yang berkaitan dengan ekonomi perdagangan ayam kampung di pasar tradisional Kota Bengkulu belum diteliti sehingga perlu dilakukan penelitian, terutama yang berkaitan dengan pendapatan dan kelayakan usaha.

Penelitian ini bertujuan untuk menganalisis ekonomis perdagangan ayam kampung di pasar tradisional kota Bengkulu, terutama pendapatan pedagang dan kelayakan usaha. Adapun manfaat dari penelitian adalah untuk mendapatkan data dasar dan informasi yang berkaitan dengan ekonomi perdagangan ayam kampung di pasar tradisional. Hasil dari penelitian ini dapat digunakan sebagai bahan masukan dalam pengembangan pasar unggas lokal.

\section{MATERI DAN METODE}

\section{Lokasi Penelitian}

Penelitian dilakukan di Pasar Tradisional di Kota Bengkulu yang di dalamnya dijumpai pedagang ayam kampung. Berdasarkan survei pendahuluan diperoleh dua pasar yaitu Pasar Panorama dan Pasar Minggu.

\section{Penentuan Responden}

Responden dalam penelitian ini adalah pedagang ayam kampung yang berada di pasar Minggu dan Pasar Panorama. Penelitian dilakukan dengan metode survei dengan responden ditentukan secara purposif yaitu seluruh pedagang ayam kampung di kedua pasar tersebut.

\section{Data Dikumpulkan dan Metode Pengumpulan Data}

Data yang dikumpulkan meliputi : data responden, data teknis perdagangan ayam kampung di pasar tradisional dan data untuk analisis ekonomis perdagangan ayam kampung. Data responden meliputi : nama, umur, jenis kelamin, pendidikan, pekerjaan utama, jumlah tanggungan keluarga, dan pengalaman berdagang ayam kampung. Data teknis meliputi : fasilitas teknis, cara pengadaan ayam yang diperdagangkan, pemeliharaan dan penampungan sebelum dijual, dan sistim penjualan (hidup atau dipotong). Sedangkan data untuk analisis ekonomi meliputi : input (pembelian ayam dagangan, biaya sarana tempat penjualan, biaya tenaga kerja, biaya pakan dan obat-obatan, biaya transportasi, sewa tempat, dan biaya keamanan) dan output (jumlah ayam yang dijual dan harga jual ayam). Data dikumpulkan dengan cara observasi dan wawancara serta pengisian daftar pertanyaan.

\section{Analisis Data}

Data yang diperoleh dari survei ditabulasi kemudian dihitung pendapatan pedagang ayam kampung dan $\mathrm{R} / \mathrm{C}$ rasio menurut Soekartawi (1995). R/C digunanakan untuk mengetahui apakah berdagang ayam kampung menguntungan atau tidak. Jika nilai $\mathrm{R} / \mathrm{C}$ lebih besar dari 1 maka usaha perdagangan ayam kampung menguntungkan, jika nilai $\mathrm{R} / \mathrm{C}$ lebih kecil dari 1 maka usaha perdagangan ayam kampung rugi, dan jika $\mathrm{R} / \mathrm{C}=1$ maka usaha perdagangan ayam kampung impas (tidak untung dan tidak rugi).Untuk mengetahui faktor-faktor yang berpengaruh terhadap pendapatan pedagang ayam kampung dilakukan analisis regresi linier berganda dengan persamaan $\mathrm{Y}=$ $a+b 1 X 1+b 2 X 2+b 3 X 3+b 4 X 4+b 5 X 5$, dimana $Y=$ pendapatan, $\mathrm{a}=$ konstanta, $\mathrm{X} 1=$ biaya pakan, $\mathrm{X} 2=$ jumlah ayam dibeli (ekor), X3=harga beli ayam (Rp/ekor), $\mathrm{X} 4=$ harga jual ayam (Rp/ekor), dan X5=biaya transportasi.

Untuk mengetahui ada atau tidaknya korelasi antar variabel bebas dilakukan uji multikolinieritas. Jika nilai korelasi (r) diantara variabel bebas lebih besar dari 0,85 maka terjadi multikolinieritas (Widarjono, 2007; Dewanti dan Sihombing, 2012). Uji statistik yang dilakukan meliputi uji $\mathrm{F}$ dan uji t. Untuk mengetahui ada pengaruh atau tidak dari variabel bebas secara bersama-sama terhadap pendapatan pedagang ayam kampung dilakukan Uji Fisher (Gujarati, 1999). Koefisien determinasi $\left(\mathrm{R}^{2}\right)$ digunakan untuk mengetahui berapa besar variabel bebas $(\mathrm{X} 1, \mathrm{X} 2, \mathrm{X} 3, \mathrm{X} 4$, dan $\mathrm{X} 5)$ dapat menjelaskan variabel terikat (Y). Uji t digunakan untuk menguji pengaruh masing-masing variabel bebas terhadap pendapatan pedagang ayam kampung (Gujarati, 1999). Pengolahan data dilakukan dengan menggunakan SPSS versi 13.0.

\section{HASIL DAN PEMBAHASAN}

\section{Karakteristik Responden}

Responden dalam penelitian ini adalah pedagang ayam kampung yang berdagang di pasar Minggu sebanyak 5 orang dan di pasar 
Panorama 6 orang, sehingga total responden pedagang ayam kampung berjumlah 11 orang. Dari jumlah tersebut 9 orang atau $81,82 \%$ berjenis laki-laki dan 2 orang atau $18,18 \%$ berjenis perempuan. Umur responden berkisar antara 30 tahun sampai 50 tahun, dengan rincian sebagai berikut : umur 30 sampai 35 tahun ada 4 orang atau $36,36 \%$, umur 36 tahun sampai 40 tahun ada 4 orang atau $36,36 \%$, umur 41 tahun sampai 45 tahun ada 2 orang atau18,18\% dan umur 45 tahun sampai 50 tahun ada 1 orang atau $9,1 \%$. Pendidikan responden terdiri dari beberapa tingkatan yaitu tidak tamat SD ada 2 orang atau $18.18 \%$, tamat SMP ada 2 orang atau $18,18 \%$, dan tamat SLTA ada 7 orang atau 63,64\%. Sedangkan jumlah anggota keluarga bervareasi antar responden, yaitu : jumlah anggota 1 orang ada 2 orang responden atau 18,18\% (belum kawin), 2 sampai 3 orang ada 6 orang responden atau $54,55 \%$, dan 4 sampai 7 orang ada 3 orang atau $27,27 \%$.

\section{Fasilitas Teknis Perdagangan Ayam Kampung di Pasar Tradisional}

Fasilitas teknis yang digunakan oleh pedagang ayam kampung di pasar tradisional kota Bengkulu terdiri dari kios, kandang penampung, tempat pakan dan tempat minum, alat pemotong (pisau), timbangan, meja dan kursi, alat cabut bulu, alat penampung daging hasil potongan, dan tempat menampung limbah. Berdasarkan pengamatan diperoleh hasil bahwa $54,55 \%$ menggunakan kandang besi, dan 45,45 \% menggunakan kandang kayu. Dari kandang yang digunakan dilengkapi dengan tempat pakan dan tempat air minum $81,82 \%$ dan $18,18 \%$ tidak melengkapi tempat makan dan tempat air minum. Responden menggunakan timbangan 81,82\% dan 18,18 \% tidak menggunakan timbangan. .Responden menggunakan meja dan kursi $100 \%$. Responden menggunakan alat pencabut bulu dan pemanas air 18,18 \% dan 81,82 \% tidak menggunakan alat pencabut bulu dan pemanas air.

\section{Pengadaan ayam kampung}

Ayam kampung yang dijual di pasar berasal dari memelihara sendiri, pembelian di pasar, dan pembelian di kampung. Dari 11 responden 5 orang atau $45,45 \%$ membeli di pasar, memelihara sendiri dan membeli di pasar 1 orang atau $9,1 \%$, membeli di pasar dan membeli di kampung dan membeli di kampung 3 orang atau $27,27 \%$, memelihara dan membeli di kampung dan membeli di pasar ada 2 orang atau
18,18\%. Pengadaan ayam dagangan paling banyak responden membeli di pasar, yaitu $45,45 \%$. Sedang sisanya adalah sebagai berikut : $9,1 \%$ responden pengadaan ayam dengan memelihara sendiri + membeli di pasar, 27,27\% membeli di pasar + membeli di kampung, dan $18,18 \%$ memelihara + membeli di pasar+membeli di kampung. Membeli ayam dagangan di pasar akan menekan biaya dan waktu serta tenaga oleh karena itu pembelian ayam di pasar akan lebih menguntungkan. Sedangkan membeli ayam dagangan di kampung akan menambah biaya yang dikeluarkan untuk transportasi sehingga biaya pengadaan akan lebih mahal. Prahmadiyan (1999) mengemukakan bahwa untuk pengadaan pemasaran ayam kampung biaya pengadaan pemasaran tertinggi ditanggung oleh pedagang antar daerah karena jarak yang jauh, resiko sakit dan kematian. Total ayam kampung yang dibeli oleh seluruh pedagang adalah 1855 ekor/bulan dengan ratarata 169 ekor per pedagang per bulan, dengan jumlah pembelian terendah adalah 116 ekor per bulan dan tertinggi 254 ekor per bulan. Rata harga pembelian ayam oleh pedagang bervariasi dari harga terendah Rp 45.000,- per ekor dan tertinggi Rp 55.800,- per ekor dengan rata-rata Rp 50.345,45 per ekor.

\section{Sistim Penjualan Ayam Kampung di Pasar Tradisional Kota Bengkulu}

Penjualan ayam pada konsumen terdiri dari dua cara yaitu dijual hidup dan dijual dalam bentuk daging (ayam dipotong di tempat penjualan). Dari pengamatan diperoleh data bahwa 18,18 \% menjual ayam dalam kondisi hidup dan 81,82\% menjual ayam dalam kondisi hidup dan dipotong. Penjualan dilakukan terhadap konsumen yang meliputi orang umum dan restoran (pelanggan). Pedagang menjual ayam kepada orang umum sebanyak $81,18 \%$ dan menjual kepada orang umum dan pelanggan sebesar $18,18 \%$. Pedagang menggunakan tenaga kerja 2 orang sebesar 9,09\% dan 90,91 orang menggunakan tenaga kerja 1 orang. Harga jual ayam kampung bervariasi tergantung dari umur dan jenis kelamin dan kondisi ayam gemuk atau kurus. Harga jual ayam dewasa per ekor paling rendah adalah $\mathrm{Rp} 71.500$,- dan paling tinggi adalah $\operatorname{Rp} 85.000,-$.

\section{Biaya Perdagangan Ayam Kampung}

Biaya perdagangan ayam kampung di pasar tradisional meliputi biaya tetap dan biaya tidak tetap. Biaya tetap terdiri dari biaya 
penyusutan kandang dan alat, sewa tempat, dan biaya keamanan. Biaya tetap paling rendah adalah Rp 893.333,- per pedagang per bulan dan tertinggi adalah Rp 1.010.000,- per pedagang per bulan dengan rata-rata sebesar Rp 943.333,- per pedagang per bulan (Tabel 2) atau 9,83\% (Tabel 1). Sedangkan biaya tidak tetap terdiri dari pembelian ayam, biaya pakan, dan biaya transportasi. Biaya tidak tetap paling rendah adalah $\mathrm{Rp} 6.038 .500,-$ per pedagang per bulan dan paling tinggi Rp 14.294.280,- dengan ratarata $\mathrm{Rp}$ 8.650.645,-per pedagang per bulan (Tabel 2) atau 90,17\% (Tabel 1). Dalam penelitian ini biaya tenaga kerja tidak diperhitungkan karena hanya menggunakan tenaga kerja keluarga yang berjumlah 1 orang dan tidak ada penambahan tenaga kerja dari luar sehingga tidak mengeluarkan biaya tenaga kerja. Rata-rata biaya produksi adalah Rp 9.593.979,per pedagang per bulan (Tabel 2).

Tabel 1. Rata-rata biaya yang dikeluarkan oleh pedagang ayam kampung

\begin{tabular}{lrr}
\hline Komponen biaya & $\begin{array}{l}\text { Rata-rata biaya } \\
\text { (Rp/pedagang/bulan) }\end{array}$ & $\begin{array}{c}\text { Persentase } \\
(\%)\end{array}$ \\
\hline Biaya tetap & & \\
$\quad$ Biaya penyusutan kandang & & \\
$\quad$ dan alat & 160.606 & 1.67 \\
$\quad$ Biaya keamanan & 46.363 & 0.48 \\
$\quad$ Sewa tempat & 736.364 & 7.68 \\
Jumlah & 943.333 & 9.83 \\
& & \\
Biaya tidak tetap & & \\
$\quad$ Pembelian ayam & 8.511 .480 & 88.72 \\
$\quad$ Biaya pakan & 50.756 & 0.53 \\
$\quad$ Biaya transportasi & 88.409 & 0.92 \\
Jumlah & 8.650 .645 & 90.17 \\
\hline Total biaya & 9.593 .979 & 100.00 \\
\hline
\end{tabular}

\section{Penerimaan dan Pendapatan Pedagang Ayam Kampung}

Penerimaan pedagang ayam kampung dari usaha perdagangan ayam kampung merupakan seluruh penerimaan dari penjualan ayam yang diperdagangkan. Pada Tabel 2 terlihat bahwa penerimaan responden meliputi penerimaan dari penjualan ayam kampung. Penerimaan pedagang dari penjualan ayam yang tertinggi adalah $\mathrm{Rp}$ 16.881.150,- per bulan dan terendah $\mathrm{Rp}$ 8.600.000,- per bulan dengan rata-rata $\mathrm{Rp}$ 11.985.650,- per peternak per bulan (Tabel 2).

Besarnya pendapatan pedagang ayam kampung dihitung dengan menggunakan analisis biaya dan penerimaan (Tabel 2).

Analisis pendapatan diperoleh dari perhitungan selisih antara penerimaan dengan biaya produksi. Tabel 2 menunjukkan bahwa pendapatan pedagang ayam kampung tertinggi Rp 4.175.390,- per bulan dan terendah $\mathrm{Rp} 1.023 .917,-$ per bulan dengan rata-rata $\mathrm{Rp}$ 2.389.626,- per pedagang per bulan (Tabel 2). Pendapatan tersebut dapat digunakan acuan pedagang ayam kampung dalam mengembangkan usahanya. Disamping itu dapat digunakan bagi masyarakat yang ingin berkecimpung didalam perdagangan ayam kampung.

Dewanti dan Sihombing (2012) mengemukakan bahwa pendapatan rata-rata peternak dapat memberikan suatu gambaran yang jelas tentang pentingnya seorang peternak mengembangkan usahanya walaupun dalam usaha tersebut memerlukan biaya produksi yang semakin besar. Biaya produksi yang besar dan seimbang dengan skala usaha, dan system pengelolaan optimal maka pendapatan peternak akan meningkat. (Triana et al., 2007). 
Tabel 2. Total biaya, penerimaan dan pendapatan pedagang ayam kampung di Kota Bengkulu

\begin{tabular}{crrrrrr}
\hline $\begin{array}{c}\text { No } \\
\text { Responden }\end{array}$ & $\begin{array}{c}\text { Biaya } \\
\text { tetap } \\
\text { Rp/bulan })\end{array}$ & $\begin{array}{c}\text { Biaya tidak } \\
\text { tetap } \\
\text { (Rp/bulan) }\end{array}$ & $\begin{array}{c}\text { Total biaya } \\
\text { (Rp/bulan) }\end{array}$ & $\begin{array}{c}\text { Penerimaan } \\
\text { (Rp/bulan) }\end{array}$ & $\begin{array}{c}\text { Pendapatan } \\
\text { (Rp/bulan) }\end{array}$ & R/C \\
\hline 1 & 968.333 & 9.984 .000 & 10.952 .333 & 11.976 .250 & 1.023 .917 & 1.09 \\
2 & 1.010 .000 & 10.159 .610 & 11.169 .610 & 15.345 .000 & 4.175 .390 & 1.37 \\
3 & 968.333 & 6.451 .500 & 7.419 .833 & 9.702 .000 & 2.282 .167 & 1.31 \\
4 & 968.333 & 10.746 .879 & 11.715 .212 & 15.372 .500 & 3.657 .288 & 1.31 \\
5 & 1.010 .000 & 7.619 .708 & 8.629 .708 & 10.664 .500 & 2.034 .792 & 1.24 \\
6 & 968.333 & 7.741 .500 & 8.709 .833 & 11.942 .500 & 3.232 .667 & 1.37 \\
7 & 893.333 & 14.294 .280 & 15.187 .613 & 16.881 .150 & 1.693 .537 & 1.11 \\
8 & 910.000 & 6.840 .574 & 7.750 .574 & 10.230 .000 & 2.479 .426 & 1.32 \\
9 & 893.333 & 6.038 .500 & 6.931 .833 & 8.600 .000 & 1.668 .167 & 1.24 \\
10 & 893.333 & 6.444 .574 & 7.337 .907 & 9.009 .000 & 1.671 .093 & 1.23 \\
11 & 893.333 & 8.858 .476 & 9.751 .809 & 12.119 .250 & 2.367 .441 & 1.24 \\
Rata-rata & 943.333 & 8.650 .645 & 9.593 .979 & 11.985 .650 & 2.389 .626 & 1.26 \\
SD & 47.434 & 2.490 .679 & 2.493 .079 & 2.776 .825 & 950.744 & 0.09 \\
\hline
\end{tabular}

\section{Rasio Penerimaan dan Biaya}

Rasio penerimaan dan biaya (R/C) merupakan hasil penjualan ayam dagangan dibagi dengan seluruh biaya yang dikeluarkan. Tabel 2 menunjukkan bahwa nilai $\mathrm{R} / \mathrm{C}$ tertinggi 1,37 dan terendah 1,09 dengan rata-rata 1,26. $\mathrm{R} / \mathrm{C}$ secara keseluruhan lebih besar dari 1 , sehingga berdagang ayam kampung menguntungkan.

\section{Analisis Regresi Faktor-faktor yang Mempengaruhi Pendapatan}

Berdasarkan analisis regresi linier berganda diperoleh persamaan regresi $\mathrm{Y}=-705.323+10,64 \mathrm{X} 1+17.789,28 \mathrm{X} 2-$ 229,57X3 + 148,57X4-2,89X5. Berdasarkan persamaan tersebut, masing-masing variabel dapat digambarkan pengaruhnya terhadap pendapatan pedagang ayam kampung di pasar tradisional Kota Bengkulu.

Uji multikolinieritas bertujuan untuk menguji apakah model regresi ditemukan adanya korelasi di antara variabel bebas. Menurut Widarjono (2007), Jika nilai korelasi (r) diantara variabel bebas lebih besar dari 0,85 maka terjadi multikolinieritas. Nilai koefisien korelasi antar variabel bebas dapat dilihat pada Tabel 4. Berdasarkan analisis menunjukkan bahwa nilai koefisien korelasi (r) diantara variabel bebas kurang dari 0,85 sehingga dapat dikatakan bahwa data tidak terjadi multikolinieritas.

Uji $\mathrm{F}$ menunjukkan bahwa nilai Fhitung 64,99 (Tabel 3) dengan tingkat signifikansi lebih kecil dari $1 \%$ sehingga variabel bebas (biaya pakan, jumlah ayam dibeli, harga beli ayam, harga jual ayam, dan transportasi) berpengaruh sangat nyata $(p<0.01)$ terhadap pendapatan.

Dari hasil analisis regresi diperoleh nilai koefisien determinasi $\left(\mathrm{R}^{2}\right)$ adalah 0,985 sehingga pendapatan $98,5 \%$ ditentukan oleh variabel bebas, dan 1,5\% ditentukan oleh variabel lain yang tidak diteliti dalam penelitian ini. Berdasarkan uji $\mathrm{F}$ diperoleh hasil bahwa variabel tidak bebas (Y) dipengaruhi oleh variabel bebas (X), sehingga dapat diduga salah satu atau lebih dari variabel bebas berpengaruh terhadap variabel tidak bebas $Y$.

Uji t menunjukkan bahwa jumlah ayam dibeli (X2), harga beli ayam (X3), dan harga jual ayam (X4) berpengaruh sangat nyata $(\mathrm{P}<0,01)$ terhadap pendapatan (Tabel 3). Begitu juga transportasi (X5) berpengaruh terhadap pendapatan $(\mathrm{P}<0,05)$. Sedangkan biaya pakan (X1) tidak berpengaruh terhadap pendapatan $(\mathrm{P}>0.05)$. 
Tabel 3. Hasil analisis regresi berganda antara variable dependen (Y) dengan variabel independent $(\mathrm{X})$

\begin{tabular}{lccl}
\hline \multicolumn{1}{c}{ Variabel } & Koefisien regresi & t hitung & Sig. \\
\hline X1 (Biaya pakan) & 10,64 & 0,79 & 0,465 \\
X2 (Jumlah ayam dibeli) & $17.789,28$ & 6,34 & 0,001 \\
X3 (Harga beli ayam) & $-229,57$ & $-6,98$ & 0,001 \\
X4 (Harga jual ayam) & 48,57 & 9,89 & 0,000 \\
X5 (Biaya transportasi) & $-2,89$ & $-2,93$ & 0,033 \\
Konstanta & -705.323 & & \\
Fhitung & 64,99 & & 0,000 \\
$\mathrm{R}^{2}$ & 0,985 & & \\
R2 adjusted & 0,97 & & \\
Variabel terikat $=\mathrm{Y}$ & & & \\
(Pendapatan) & & & \\
\hline
\end{tabular}

Tabel 4. Koefisien korelasi antar variable bebas

\begin{tabular}{ccccccc}
\hline & $\mathrm{Y}$ & $\mathrm{X} 1$ & $\mathrm{X} 2$ & $\mathrm{X} 3$ & $\mathrm{X} 4$ & $\mathrm{X} 5$ \\
\hline $\mathrm{Y}$ & 1 & 0,680 & 0,256 & $-0,437$ & 0,462 & 0,002 \\
$\mathrm{X} 1$ & 0,680 & 1 & 0,619 & $-0,464$ & $-0,18$ & 0,544 \\
$\mathrm{X} 2$ & 0,256 & 0,619 & 1 & 0,191 & $-0,469$ & 0,495 \\
$\mathrm{X} 3$ & $-0,437$ & $-0,46$ & 0,191 & 1 & 0,122 & $-0,32$ \\
$\mathrm{X} 4$ & 0,462 & $-0,18$ & 0,469 & 0,122 & 1 & $-0,562$ \\
$\mathrm{X} 5$ & 0,002 & 0,544 & 0,495 & $-0,32$ & $-0,562$ & 1 \\
\hline
\end{tabular}

Harga beli ayam dan transportasi menunjukkan angka negatif yang berarti bahwa semakin meningkat harga beli per ekor ayam dan biaya transportasi akan menurunkan pendapatan. Menurut Cahyono (2011), bahwa harga jual beli ayam buras di pasaran selalu berubah dari waktu ke waktu, hal ini dikarenakan adanya pengaruh dari pangsa pasar, sehingga memberikan pengaruh terhadap pendapatan. Pembelian ayam pada saat harga ayam mengalami kenaikan bisa memberikan pengaruh menurunnya pendapatan.

\section{KESIMPULAN}

Berdasarkan penelitian dapat disimpulkan bahwa pendapatan pedagang ayam kampung di pasar tradisional Kota Bengkulu tertinggi Rp 4.175.390,- per bulan dan terendah $\mathrm{Rp} 1.023 .917,-$ per bulan dengan rata-rata $\mathrm{Rp} 2.389 .626$,- per pedagang per bulan. Beberapa faktor yang berpengaruh terhadap pendapatan adalah jumlah ayam dibeli, harga beli ayam, harga jual ayam, dan transportasi. Nilai R/C tertinggi adalah 1,37 dan terendah 1,09 dengan rata-rata 1,26 sehingga usaha perdagangan ayam kampung di pasar tradisional Kota Bengkulu menguntungkan dan secara ekonomi layak untuk diusahakan.

\section{DAFTAR PUSTAKA}

Aman, Y 2011. Ayam Kampung Unggul. Penerbit Penebar Swadaya. Jakarta.

Anonim. 2007. Peraturan Presiden Republik Indonesia Nomor 112 tahun 2007 Tentang Penataan Dan Pembinaan Pasar Tradisional, Pusat Perbelanjaan Dan Toko Modern.

Anonim. 2018. Statistik Peternakan dan Kesehatan Hewan 2018. Direktorat Jenderal Peternakan dan Kesehatan 
Hewan. Kementerian Pertanian Republik Indonesia.

Cahyono, B. 2011. Ayam Buras Pedaging. Penebar Swadaya. Jakarta.

Dewanti, R. dan G. Sihombing. 2012. Analisis pendapatan usaha peternakan ayam buras (Studi Kasus di Kecamatan Tegalombo, Kabupaten Pacitan). Buletin Peternakan. 36(1): 48-56.

Gujarati. D. 1999. Basic Econometric. PT Erlangga. Jakarta.

Kim, H. R. 2015. Culture and tourismoriented local traditional market strategies in Korea. Proceedings of the First European Academic Research Conference on Global Business, Economics, Finance and Social Sciences (EAR15 Italy Conference). Milan-Italy, June 30July 1-2, 2015.

Krista, B. 2010. Beternak dan Bisnis Ayam Kampung. Agromedia Pustaka. Jakarta:

Nasution, A. F., E. Dihansih, dan Anggraeni. 2016. Pengaruh substitusi pakan komersil dengan tepung ampas kelapa terhadap sifat fisik dan organoleptik daging ayam kampung. Jurnal Pertanian. 7(1): 14-22.
Pane, F. A. 2006. Komposisi asam amino daging ayam kampung, broiler dan produk olahannya. Program Studi Teknologi Hasil Ternak, Fakultas Peternakan, Institut Pertanian Bogor. Bogor.

Seokartawi,1995. Analisis Usaha Tani. UI Press. Jakarta.

Soedjana, T.D., H.C. Krispercheer dan Sugiyanto. 1983. The marketing of small ruminant East Java. Proc. Pertemuan Ilmiah Penelitian Ruminansia Kecil. Pusat Penelitian dan Pengembangan Peternakan. Bogor.

Teti, S. 2002. Tinjauan ternak usaha ayam buras dalam upaya pemberdayaan ekonomi masyarakat. Institut Pertanian Bogor. Bogor. (Skripsi).

Triana, A., T. Salam, dan M. Muis. 2007. Analisis pendapatan usaha peternakan ayam ras petelur periode layer di Kecamatan Cenrana Kabupaten Maros. Jurnal Agrisistem. 3(1): 1115.

Widarjono. 2007. Ekonometrika: Teori dan Aplikasi untuk Ekonomi dan Bisnis. Ekonisia. Fakultas Ekonomi UII. Yogyakarta.

Yuwanta, T. 2008. Dasar Ternak Unggas. Kanisius. Yogyakarta. 